\title{
ANALISIS PENERAPAN KESELAMATAN DAN KESEHATAN KERJA (K3) PADA BAGIAN LABORATORIUM DI PT TIRTA INVESTAMA AQUA MAMBAL (Sebuah Kajian Dari Perspektif Manajemen Sumber Daya Manusia)
}

\author{
I.A.K.P. M. Devi ${ }^{1}$, Trianasari ${ }^{2}$ \\ 1,2 Jurusan Manajemen, Universitas Pendidikan Ganesha, Singaraja \\ e-mail: idaayuputrimayunidevi@gmail.com, nanatrianasari01@gmail.com
}

\begin{abstract}
Abstrak
Penelitian ini bertujuan untuk menganalisis penerapan sistem Keselamatan dan Kesehatan kerja pada karyawan bagian laboratorium PT Tirta Investama AQUA Mambal. Pendekatan yang digunakan dalam penelitian ini termasuk jenis penelitian deskriptif kualitatif, dengan menggunakan wawancara dan studi dokumen sebagai metode pengumpulan data. Subjek dalam penelitian ini adalah Kepala Laboratorium dan Staff Laboratorium PT Tirta Investama AQUA Mambal yang berjumlah 10 orang. Hasil Penelitian ini menunjukkan bahwa (1) Penerapan K3 yang baik dilakukan dengan cara baik akan menciptakan suasana kerja yang aman dan sehat, (2) Dampak yang ditimbulkan dari adanya pelanggaran K3 dapat menimbulkan cedera dan kematian bagi karyawan (3) Upaya yang dilakukan untuk meminimalisir kecelakaan K3 yaitu salah satunya dengan pemberian sanksi yang tegas bagi karyawan.
\end{abstract}

Kata Kunci : penerapan K3, pelanggaran K3, pencegahan, prosedur K3

\begin{abstract}
The aim of this study was to analyze the implementation of safety and health management system in a workplace to the laboratory employees of PT Tirta Investama AQUA Mambal. The approach used in this research was descriptive qualitative. The data were collected by conducting interviews and document studies. The subjects of this study were 10 people, including the Head of Laboratory and Laboratory Staffs of PT Tirta Investama AQUA Mambal. The results of this study indicated that (1) A good K3 implementation would create a safe and healthy work atmosphere, (2) The consequences of $K 3$ violations could result in injured and death employee (3) One particular attempt that can be used to minimize the workplace hazards was by decisively giving penalty to the employees.
\end{abstract}

Keywords : implementation of K3, K3 violations, prevention, K3 procedures

\section{Pendahuluan}

Sumber daya manusia adalah salah satu sumber daya organisasi yang memegang peranan penting dalam mencapai tujuan disuatu organisasi. Oleh karena itu, pentingnya peran manusia di dalam persaingan baik jangka pendek maupun jangka panjang dalam agenda bisnis organisasi haruslah mempunyai nilai yang lebih besar dari pada organisasi lain. Jika suatu organisasi dapat menarik perhatian masyarakat akan keunggulannya dibandingkan organisasi lain, maka dikatakan organisasi tersebut dapat berhasil mempengaruhi pasar, Bangun (2012)

Manajemen sumber daya manusia sangat erat kaitannya dengan manusia melalui aktivitas organisasi dan fungsi operasionalnya. Oleh karena itu, manajemen sumber daya manusia dapat dijelaskan sebagai proses perencanaan, pengorganisasian, kepegawaian, mobilisasi dan pengendalian. Selain itu, sumber daya manusia juga diartikan sebagai pengembangan, kompensasi, pengintegrasian, pemeliharaan dan pembagian kerja untuk mencapai suatu tujuan di dalam organisasi.

Manajemen sumber daya manusia adalah salah satu aset perusahaan yang memiliki peran penting dalam mencapai tujuannya, khususnya di era industrialisasi yang semakin berkembang seperti sekarang ini. Pada perusahaan tertentu, pesatnya pertumbuhan teknologi dan informasi belum dapat mengganti keberadaan sumber daya manusia secara utuh. Maka dari itu, manajemen sumber daya manusia harus diberdayakan sedemikian rupa agar terkoordinasi dengan baik. Di dalam pengembangan sumber daya manusia harus memiliki 
seorang pengelola yang dapat mengelola sumber daya secara sistematis dan efektif. Bagi pengelola sumber daya manusia salah satu hal yang terpenting adalah sistem keselamatan dan kesehatan kerja, karena manusia merupakan pelaksana produksi yang aman. Tanpa dukungan dan kehadiran sumber daya manusia maka proses produksi dan alat produksi tidak akan berjalan (Kusuma, 2010).

Banyak perusahaan telah menerapkan sistem keselamatan dan kesehatan kerja untuk mengurangi risiko kecelakaan kerja di dalam suatu perusahaan atau industri. Dalam peraturan pemerintah yang terdapat dalam Pasal 1 Ayat (1) Peraturan Pemerintah No.50 Tahun 2012 Tentang Penerapan Sistem Manajemen Keselamatan dan Kesehatan Kerja (K3), setiap perusahaan memang diwajibkan untuk mengikutkan karyawannya dalam program kesehatan kerja. Tujuan diadakannya suatu sistem penerapan K3 di suatu industry atau tempat kerja adalah untuk memastikan bahwa pekerja dan personel lainnya di tempat kerja selalu dalam keadaan aman dan sehat, serta memastikan penggunaan semua sumber produksi secara aman dan efektif. (Suma'mur, 2006).

Keselamatan dan kesehatan kerja adalah salah satu hal yang menarik perhatian banyak organisasi saat ini, karena mencakup masalah kemanusiaan, keuangan dan manfaat ekonomi, tanggung jawab, hukum dan image organisasi itu sendiri, semuanya berada pada level yang sama. Kalaupun perilaku di lingkungan dan faktor lain dari luar industri ada perubahan perilaku itu juga sangat penting, Ervianto (dalam Soputan, 2014). Keselamatan kerja mengacu pada perlindungan keselamatan kerja semua pegawai dan seua yang ada dilingkungan perusahaan. Perlindungan mengacu pada kesehatan fisik dan mental pekerja karena lingkungan kerja perusahaan yang ada. Hampir tidak ada karyawan perusahaan yang menerapkan rencana produksi keselamatan yang menderita cedera jangka pendek atau jangka panjang karena pekerjaan.

Berbagai penelitian menunjukkan bahwa terdapat hubungan yang signifikan dengan hasil organisasi. Konsep keselamatan dan kesehatan kerja bukanlah hal yang awam lagi bagi pihak perusahaan. K3 sendiri merupakan tugas perusahaan yang harus dilaksanakan untuk melindungi pekerja atau karyawan. Orang sehat akan dapat melakukan aktivitas secara normal tanpa memandang status fisik, mental dan emosionalnya. Setiap anggota organisasi menginginkan keselamatan dan kesehatan kerja. Demikian pula, pengusaha berupaya keras untuk memberikan tunjangan kepada karyawan. Perusahaan atau industri besar biasanya mempunyai departemen yang bertugas dalam keselamatan dan kesehatan kerja karyawannya, sedangkan perusahaan atau industri kecil biasanya diurus langsung oleh departemen atau manajer sumber daya manusia, Bangun (2012)

Program Keselamatan dan Kesehatan Kerja (K3) dirancang untuk memastikan keselamatan semua pekerja untuk memastikan bahwa mereka mematuhi atau mematuhi segala aturan perundang-undangan keselamatan dan kesehatan kerja atau K3, sehingga mereka tidak terluka atau menyebabkan sakit saat bekerja. Tercermin dalam perubahan sikap terhadap keselamatan di tempat kerja Dewi (Octaviani, 2006). K3 sangat perlu dipahami dan diterapkan di perusahaan, terutama dalam hal pekerjaan. Hal ini terkait dengan perlindungan pekerja dari kecelakaan kerja. Untuk meminimalisir adanya kecelakaan kerja maka pengertian dan praktek K3 di suatu perusahaan perlu disebarkan secara baik dan benar. (Sofyan, 2017). Akibat operasi program K3 yang tidak normal, sering terjadi kecelakaan di tempat kerja dan risiko penyakit akibat pekerjaan.

Kecelakaan kerja biasanya terjadikarena dua faktor, dimana faktor tersebut terdiri dari manusia dan lingkungan. Faktor manusia, adalah perilaku tidak aman yang dibuat oleh manusia, seperti pelanggaran yang disengaja terhadap peraturan keselamatan wajib atau kurangnya keterampilan pekerja. Pada saat yang sama, faktor lingkungan adalah keadaan lingkungan kerja yang dirasa tidak aman, termasuk peralatan atau mesin. Tingginya insiden kecelakaan industri disebabkan oleh disfungsionalnya manajemen keselamatan dan kesehatan kerja, Silaban (2009). Ketidakpatuhan tidak terjadi karena mereka tidak tahu apa yang mereka lakukan dan apa yang mereka lakukan. Tetapi bisa juga karena mereka membuat kesalahan, dan tidak tahu ada prosedur yang mengatur pekerjaan secara aman.

Keselamatan dan kesehatan kerja (K3) adalah salah satu hal penting dari manajemen, pencegahan dan pengelolaan adanya bahaya. Jika pengendalian bahaya manusia gagal, 
bencana akan datang dengan konsekuensi yang buruk. Biasanya, karena kesalahan atau pelanggaran aturan dan prosedur, orang terluka atau bahkan mengalami bencana. Inilah mengapa pemilik atau manajemen perusahaan didorong untuk mengambil tindakan preventif. Kecelakaan biasanya terjadi karena dua jenis perilaku yang tidak benar. Untuk menanggulanginya, Anda dapat memperbaiki salah satu perilaku tidak aman berikut.

Sistem manajemen K3 diperlukan karena merupakan kebutuhan organisasi perusahaan baik untuk internal dalam hal lancarnya proses produksi maupun eksternal seperti mematuhi legislasi dan kontrak kerja, Marthinus (2019). Sistem manajemen keselamatan dan kesehatan kerja berada pada peraturan Pasal 1 Menteri Tenaga Kerja PER.05 / MEN / 1996, dan sistem manajemen keselamatan dan kesehatan kerja (SMK3) merupakan salah satu sistem manajemen secara keseluruhan, yang mencakup pengendalian dan aktivitas kerja Risiko yang relevan untuk menetapkan latar belakang yang aman dan efektif untuk merumuskan, menerapkan, mengevaluasi dan memelihara struktur organisasi, tanggung jawab, pelaksanaan, prosedur dan tempat kerja produktif yang diperlukan untuk keselamatan dan kesehatan kerja kebijakan, Bangun (2012).

Manajemen keselamatan dan kesehatan kerja (K3) memiliki berbagi tujuan dan berbagai macam manfaat. Studi Suparwo menuturkan tentang Manajemen Keselamatan dan Kesehatan Kerja Indo Garmen, Bandung, Usaha Kecil dan Mikro (2019) memaparkan bahwa penerapan di bawah pengawasan manajemen keselamatan dan kesehatan kerja dapat menimbulkan tempat kerja yang aman, sehat dan bebas polusi untuk melindungi lingkungan dan untuk mencegah pekerja menghindari kecelakaan terkait pekerjaan, sehingga menambah efisiensi dan produktivitas kerja. Selain itu, dengan sumber daya manusia yang kompeten dan lingkungan kerja yang baik di bidangnya, suasana yang aman akan sangat mengurangi risiko kecelakaan kerja bagi perusahaan.

Tujuan utama dari sistem manajemen keselamatan dan kesehatan kerja adalah untuk mengelola aktivitas organisasi, untuk mengurangi atau menghilangkan risiko kecelakaan kerja yang dialami oleh anggota organisasi, demi tercapainya keselamatan dan kenyamanan kerja, sehingga secara efektif mencapai tujuan dari organisasi. Sistem manajemen keselamatan dan kesehatan kerja (SMK3) merupakan bagian yang tak terpisahkan dari proses produksi yang bertujuan meningkatkan efisiensi dan produktivitas, serta berperan dalam upaya perlindungan investasi, Silaban (2009). Sesuai dengan ketentuan Pasal 2 Menteri Tenaga Kerja Per.05 / Men / 1996, tujuan dari sistem manajemen keselamatan dan kesehatan kerja adalah untuk mencapai manajemen sistem keselamatan dan kesehatan kerja dengan berpartisipasi di tempat kerja, ketenagakerjaan dan lingkungan kerja. Elemen dan menggabungkannya ke dalam pencegahan dan pengurangan terjadinya kecelakaan dan penyakit yang diakibatkan saat bekerja, dan untuk membangun tempat kerja yang nyaman, aman, efisien dan produktif. Penyusunan peraturan perundang-undangan mengenai sistem manajemen keselamatan dan kesehatan kerja akan memberikan manfaat bagi seluruh masyarakat, terutama para pekerja itu sendiri. Di sisi lain, penerapan sistem manajemen keselamatan dan kesehatan kerja akan membawa berbagai manfaat bagi industri. Karena hilangnya waktu, kerugian materi, dan biaya pengobatan yang disebabkan oleh cedera terkait pekerjaan, aktivitas produksi perusahaan tidak dirugikan. Karyawan akan merasa aman dan juga sejahtera untuk bekerja, maka akan meningkatkan produktifitas kerja yang baik, manfaat lain yang diperoleh adalah respon masyarakat terhadap perusahaan semakin baik dan terjalin hubungan yang baik antara karyawan dengan perusahaan, serta komitmen karyawan terhadap perusahaan juga semakin tinggi, Bangun (2012).

Dari sekian banyak perusahaan besar di Indonesia, PT Tirta Investama AQUA Mambal adalah perusahaan yang senantiasa mengedepankan keselamatan dan kesehatan kerja karyawannya. PT Tirta Investama (AQUA MAMBAL) merupakan perusahaan swasta Indonesia dalam bidang industri air minum dalam kemasan. Perusahaan menerapkan K3 pada lima prinsip dasar WISE, yaitu (1) kecelakaan nol dapat dicapai; (2) perubahan perilaku; (3) ketertiban dan kerjasama aktif; (4) manajemen; (5) keselamatan yang baik. Karena AQUA merupakan merek produk air minum dalam kemasan teratas di Indonesia, maka AQUA dijadikan rujukan atau contoh oleh perusahaan lain (terutama perusahaan yang bergerak di bidang yang sama), maka dari itu dibutuhkan penelitian ini guna mengetahui bagaimana 
penerapan keselamatan dan kesehatan kerja ( K3) di dalam Perusahaan. Karena AQUA merupakan merek produk air minum dalam kemasan teratas di Indonesia maka AQUA dijadikan rujukan atau contoh oleh perusahaan lain (terutama perusahaan yang bergerak di bidang yang sama), maka diperlukan penelitian guna mengetahui bagaimana penerapan keselamatan dan kesehatan kerja (K3) yang baik dan benar.

Berdasarkan latar belakang yang dipaparkan diatas, penelitian ini dilakukan guna (1) mengetahui penerapan sistem manajemen K3 di bagian laboratorium di PT Tirta Investama AQUA Mambal (2) mengetahui dampak yang ditimbulkan dari adanya pelanggaran yang dilakukan oleh karyawan bagian laboratorium di PT Tirta Investama AQUA Mambal (3) mengetahui upaya yang dilakukan untuk mengatatasi pelanggaran yang dilakukan oleh karyawan bagian laboratorium di PT Tirta Investama AQUA Mambal.

Penelitian ini dilakukan dengan mengacu pada beberapa literatur tentang Keselamatan dan Kesehatan Kerja (K3) yang terbagi menjadi dua definisi. Hal ini menurut Mangkunegara merupakan pemikiran dan upaya untuk menjamin keutuhan dan kesempurnaan tenaga kerja terutama lahir dan batin serta seluruh umat manusia, serta hasil karya dan budaya mereka untuk mewujudkan masyarakat yang adil dan sejahtera. Secara ilmiah K3 merupakan ilmu dan aplikasinya yang berguna untuk mencegah adanya kecelakaan ditempat kerja dan adanya penyakit akibat kerja. Menurut definisi OHSAS 18001 (2007) keselamatan dan kesehatan kerja merupakan kondisi atau faktor yang akan mempengaruhi keselamatan dan kesehatan pekerja (termasuk kontraktor dan kontraktor), tamu atau personel lain di tempat kerja.

\section{Metode}

Penelitian ini dikategorikan ke dalam penelitian deskriptif dengan pendekatan kualitatif. Metode ini adalah kajian yang menggunakan presepsi dan juga bahan-bahan tertulis untuk mengetahui hal-hal yang tidak terukur dengan pasti (intangible). Metode ini memberikan hasil temuan yang bersifat mendalam melalui data bukan angka atau non statistic. Lokasi penelitian ini adalah PT Tirta Investama (AQUA Mambal) yang terletak di Mambal, Kecamatan abiansemal, Kabupaten Badung. Penelitian ini bertujuan untuk mengetahui penerapan Keselamatan dan Kesehatan Kerja (K3) karena AQUA merupakan perusahaan terkemuka atau perusahaan yang dijadikan acuan oleh perusahaan lain.

Subyek pada penelitian ini yaitu (1) Kepala Departemen Laboratorium dan (2) Karyawan Laboratorium PT Tirta Investama (AQUA Mambal). Metode yang digunakan dalam pengumpulan data yakni dengan cara melakukan wawancara mendalam dan studi dokumen. Dimana wawancara adalah teknik pengumpulan data dengan melakukan tanya jawab dengan narasumber secara langsung, dengan kata lain wawancara adalah interaksi secara langsung antar peneliti dengan responden. Sedangkan studi dokumentasi yaitu suatu teknik pengumpulan data dengan cara mempelajari dokumen guna memperoleh data atau informasi yang berhubungan dengan masalah yang sedang diteliti.

Analisis data dalam penelitian ini bersifat deskriptif. Penelitian ini dilakukan sewaktu akan pengumpulan data dan setelah pengumpulan data telah selesai dilakukan dalam jangka waktu tertentu. Analisis data yang digunakan dalam penelitian ini adalah model rekayasa data Miles dan Huberman. Data yang pergunakan dalam penelitian ini yaitu data primer, dimana sumber data yang diperoleh langsung dari sumber asli (tidak melalui media perantara). Data primer juga berbentuk dalam opini subjek secara individual. Dalam penelitian ini, yang menjadi instrumen penelitian adalah human instrument atau peneliti itu sendiri, mulai menetapkan fokus penelitian, memilih informan sebagai sumber data, melakukan pengumpulan data, menilai kualitas data, analisis data, menafsirkan data sampai membuat kesimpulan atas temuan penelitian. Selain itu, instrumen yang digunakan adalah panduan wawancara dengan pedoman rumusan masalah. Jumlah subyek yaitu minimal 10 orang hingga tercapai saturasi data yang berarti tidak ditemukan lagi informasi baru dari subyek peneliti.

Populasi dalam penelitian ini adalah situasi sosial di PT Tirta Investama (AQUA Mambal) yaitu pelaku (actor), tempat (place), dan aktivitas (activity). Sampel data dipilih secara purposive sampling yaitu teknik penentuan sampel dengan pertimbangan tertentu, artinya informan yang dipilih yaitu orang-orang yang ahli, memiliki peran, kewenangan dan jabatan yang sesuai dengan fokus penelitian dan kebutuhan informasi. Pelaku dalam hal ini adalah 
seluruh pegawai bagian Laboratorium PT Tirta Investama (AQUA Mambal) yang berjumlah 10 orang. Kegiatan analisis data merupakan reduksi data, penyajian data, dan pengambilan kesimpulan atau verifikasi. Untuk mengetahui keabsahan data maka peneliti harus melakukan uji validitas data. Uji validitas adalah keakuratan interpretasi yang diperoleh dari hasil pengukuran atau evaluasi. Uji validitas yang digunakan pada saat penelitian ini berlangsung adalah uji reputasi. Uji kredibilitas data merupakan uji kredibilitas data penelitian. Metode pengujian melalui triangulasi. Metode ini adalah suatu teknik pengumpulan data yang menggabungkan berbagai teknik pengumpulan data dengan sumber data yang ada. Menurut Sugiono (2011) dengan menggunakan metode triangulasi diharapkan peneliti memperoleh lebih meningkatkan keakuratan data.

\section{Hasil dan Pembahasan}

Penelitian ini dilakukan dengan menggunakan analisis deskriptif kualitatif. Data yang didapat di reduksi menggunakan tabel triangulasi. Responden disini menggunakan nama samaran agar tetap menjaga kerahasiaan perusahaan. Berikut karakteristik dari responden dapat dilihat pada tabel

Tabel 1. Deskripsi Responden

\begin{tabular}{cccc}
\hline No & Informan & Jabatan & Gender \\
\hline 1 & A & Bagian Analisis Mikro & Laki-laki \\
2 & D & Bagian Analisis Fisika dan Kimia & Laki-laki \\
3 & K & Bagian Analisis Fisika dan Kimia & Laki-laki \\
4 & A & Bagian Analisis Mikro & Laki-laki \\
5 & M & Bagian Analisis Kemasan & Laki-laki \\
6 & W & Bagian Analisis Kemasan & Laki-laki \\
7 & D & Bagian Analisis Mikro & Perempuan \\
8 & N & Bagian Analisis Mikro & Laki-laki \\
9 & P & Bagian Analisis Kemasan & Perempuan \\
10 & Dw & Bagian Analisis Fisika dan Kimia & Laki-Laki \\
\hline
\end{tabular}

Berdasarkan hasil penelitian, penerapan K3 di PT Tirta Investama AQUA Mambal merupakan salah satu sikap dan perilaku pekerja yang enggan menggunakan alat pelindung diri lengkap yang disediakan perusahaan. Banyak pekerja yang mengabaikan perlengkapan keselamatan yang disediakan perusahaan untuk mencegah terjadinya kecelakaan kerja. Alasannya, pekerja merasa tidak nyaman saat menggunakan alat pelindung diri, sehingga pekerja tidak mau menggunakan alat pelindung diri secara utuh. Padahal alat pelindung diri atau APD adalah kelengkapan yang wajib digunakan saat bekerja sesuai bahaya dan risiko kerja untuk menjaga keselamatan pekerja itu sendiri dan orang di sekelilingnya. Penggunaan APD yang benar dan sesuai dengan standar keselamatan kerja seperti penggunaan jas laboratorium yang besar, penggunaan sepatu karet atau boot, sarung tangan, penutup rambut, penutup telinga, kacamata pengaman, dan juga masker dianggap terlalu rumit sehingga menyebabkan ketidaknyamanan dalam bekerja. Selain itu peraturan yang ada di PT Tirta Investama AQUA Mambal dan penggunaan alat pelindung diri membuat pekerja menyita cukup banyak waktu, sehingga membuat pekerjaan menjadi lambat. Dapat dicontohkan dengan peraturan berjalan dijalur pedestrian, dimana pekerja harus berjalan sesuai dengan 
garis yang sudah ditentukan oleh pihak perusahaan. Hal itu mengakibatkan pekerja merasa peraturan dan penggunaan APD membuat pekerjaan menjadi lambat. Hal terakhir yang membuat pekerja tidak melakukan penerapan K3 dengan baik dan benar yaitu karena kurangnya kepedulian sesama pekerja. Pentingnya kepedulian sesama pekerja atau karyawan sangat diperlukan didalam suatu perusahaan, khususnya yang berkaitan dengan keselamatan dan kesehatan kerja. Perhatian atau kepedulian sesama pekerja dapat dicontohkan dengan, memberi teguran atau nasehat kepada teman yang tidak mengikuti aturan yang telah ditetapkan oleh perusahaan, atau menegur teman karena tidak menggunakan APD dengan baik dan benar. Seperti yang dikatakan oleh Somad (2013), umumnya orang mendapatkan cidera bahkan terjadi bencana dilingkungan kerja karena mereka membuat kesalahan atau menyimpang dari ketentuan dan prosedur yang telah ditetapkan perusahaan.

Berdasarkan hasil penelitian ditemukan bahwa dampak yang ditimbulkan dari adanya pelanggaran K3 yang terjadi pada bagian Laboratorium di PT Tirta Investama AQUA Mambal yaitu beresiko terjadinya cidera dan terpapar cairan kimia berbahaya maupun terkena radiasi. $\mathrm{Hal}$ ini dapat menyebab cidera ringan dan bahkan berujung dengan kematian. Keselamatan dan kesehatan yang masih dianggap sepele oleh karyawan ini perlu adanya tindakan serius.

Selain itu dampak lain yang ditemukan yaitu, terbentuknya suatu budaya yang tidak baik dikalangan pekerja lainnya. Budaya biasanya terlahir dari kebiasaan-kebiasaan yang sering dilakukan, sama halnya dengan diperusahaan. Jika diperusahaan terdapat pekerja yang tidak mampu dan tidak mau menaati peraturan yang ada diperusahaan, pastinya akan menjadi suatu prilaku yang buruk untuk dicontoh oleh pekerja lainnya. Hal tersebut menimbulkan budaya yang buruk pula dilingkungan kerja.

Keselamatan dan kesehatan kerja atau K3 ini terdapat pada peraturan perundangundang ketenagakerjaan. Perusahaan dan karyawan sama-sama harus saling memahami mengenai keselamatan kerja sesuai dengan standar yang berlaku, salah satunya mengenai penggunaaan alat pelindung diri atau APD yang sesuai dengan standarisasi. Apabila pekerja tidak mengikuti peraturan dalam pemakaian APD, maka dapat menyebabkan cidera pada bagian tubuh tertentu dan terpapar zat-zat berbahaya. Selain menyebabkan cidera bahkan kematian, kecelakaan kerja juga akan menyebabkan penurunan produktivitas karena kelambatan produksi yang bisa mengakibatkan perusahaan mengalami kerugian. Keselamatan dan kesehatan para pekerja merupakan faktor yang harus diperhatikan untuk meningkatkan produktivitas kerja karyawan, Sedarmayanti (2009).

Dengan adanya masalah tersebut diperlukan upaya untuk menanggulangi pelanggaran K3 yang terjadi pada bagian laboratorium di PT Tirta Investama AQUA Mambal. Ada beberapa upaya yang harus dilakukan yang pertama yaitu pemberian sanksi tegas bagi pelanggar peraturan, dengan adanya sanksi yang diberikan kepada pekerja yang tidak mau mengikuti peraturan dengan baik dan benar, maka akan membuat efek jera pada pekerja tersebut. Menurut Somad (2013) para pekerja yang telah mendapatkan sanksi akan mengubah perilakunya untuk menghindari sanksi berikutnya. Jadi yang timbul keinginan mengubah perilaku berdasarkan kesadaran yang diyakini bisa bertahan untuk jangka waktu yang lama. Pemberian sanksi seharusnya tidak hanya kepada pekerja terkait saja. Hal ini dirasakan tidak adil oleh pekerja, pemberian sanksi baik adalah kepada pekerja secara individual dan juga pada pengawas dan manajernya. Sanksi diberikan jika ditemukan kesalahan sesuai dengan porsi tanggung jawab dan tingkat kelalaian yang sudah dilakukan. Ketentuan pemberian sanksi sesuai tingkatan jabatan perlu diatur secara formal dan diberlakukan dalam organisasi. Menurut Ridley (2006: 74), berbagai sanksi telah dijatuhkan terhadap karyawan yang melanggar peraturan keselamatan produksi, antara lain peringatan lisan kepada pekerja melalui kesempatan untuk memperbaiki kesalahan, dan pelatihan tambahan bila diperlukan. Selain itu, berikan kesempatan kepada karyawan untuk menyampaikan pendapat atau keluhannya. Selain itu, jika karyawan tidak berganti, perusahaan berhak mengeluarkan surat peringatan pertama dengan uraian konsekuensi yang mungkin terjadi.Jika tidak sesuai (seperti pemecatan), maka akan memberikan surat peringatan kedua kepada mereka yang ulangi instruksi yang diberikan. Pada surat peringatan pertama kemudian diberikan surat peringatan terakhir dan pernyataan tentang kemungkinan 
diberhentikan, jika tidak ada perubahan maka perusahaan dapat langsung memberhentikan karyawan tersebut.

Pekerjaan perusahaan selanjutnya adalah memberikan pelatihan tentang K3 kepada para pekerja. Pelatihan dapat memampukan karyawan untuk memahami dan memahami pentingnya keselamatan dalam bekerja agar tidak terjadi kecelakaan kerja. Menurut Moekijat (2010: 76) pelatihan berlangsung karena pendidikan seseorang pada dasarnya tidak ada habisnya. Selalu ada sesuatu untuk dipelajari. Pelatihan karyawan dapat mendorong karyawan untuk terus bekerja semaksimal mungkin dan membantu meningkatkan hasil kerjanya. Moekijat (2010: 73) menjelaskan bahwa tujuan pelatihan karyawan adalah agar karyawan memperoleh pengetahuan yang lebih baik dan lebih berguna, sehingga mampu meningkatkan keterampilan kerja mereka, dan pelatihan juga dapat membantu karyawan beradaptasi dengan metode dan proses baru yang terus diadopsi. Oleh karena itu, jika karyawan dilatih dengan benar, kecelakaan kerja yang buruk dan kerusakan pada mesin dan peralatan lain dapat diminimalkan, dan proses baru dapat terus diperkenalkan.

Selanjutnya, upaya yang dapat dilakukan untuk meminimalisir kecelakaan kerja, dapat juga dilakukan dengan cara melakukan pengawasan terhadap pekerja. Perusahaan harus memberikan pengawasan dan motivasi kepada karyawan bahwa pentingnya bekerja dengan mengikuti prosedur K3 yang baik bertujuan agar dapat mencegah terjadinya kecelakaan akibat kerja. Dalam pemberian motivasi Somad (2013) menyatakan, pentingnya untuk menanamkan bahwa tanggung jawab K3 tidak hanya untuk diri sendiri tetapi juga untuk sesama pekerja lainnya. Pekerja harus termotivasi untuk menghentikan pekerjaan orang lain yang tidak aman. Dengan motivasi dan pengetahuan K3 dapat meningkatkan kesadaran dan kewaspadaan pekerja terhadap bahaya dan cara mengatasinya sehingga memperkecil kemungkinan terjadinya kecelakaan kerja, Hanggraini (2012). Selain itu, upaya terakhir yang bisa dilakukan perusahaan yaitu dengan cara pemberian penghargaan bagi karyawan yang mampu mengikuti peraturan. Somad (2013) mengatakan penghargaan berupa surat khusus atau plakat atas upaya meningkatkan kinerja K3 yang berhasil, atau pimpinan unit langsung datang ke lokasi bekerja dan memberikan ucapan selamat atas prestasinya. Membandingkan kinerja grup yang satu dengan yang lain juga cukup efektif dalam meningkatkan kinerja K3. Cara sederhana misalnya dengan memberikan predikat hijau bagi departemen yang baik kinerjanya, predikat kuning bagi grup yang kinerjanya kurang, dan predikat hitam bagi grup yang kinerjanya tidak memuaskan. Pelaksanaan penghargaan grup seperti ini akan menciptakan suasana yang kompetitif. Namun, dalam pelaksanaannya perlu dibuat dengan sistem yang transparan, adil, dan berdasarkan data yang valid.

\section{Simpulan dan Saran}

Penerapan sistem K3 yang dilakukan PT Titra Investama AQUA Mambal belum maksimal. Dari hasil penelitian yang didapat, ditemukannya beberapa masalah yang menjadi penghambat dalam penerapan standar K3. Diantaranya karyawan yang tidak mengenakan APD atau Alat Pelindung Diri seperti yang tertera pada prosedur, kurang memahami bagaimana sistem penerapan K3 di lingkungan kerja dan budaya acuh tak acuh akan keselamatan dan kesehatan di lingkungan kerja.

Dampak yang ditimbulkan dari adanya pelanggaran K3 yaitu menyebabkan cedera yang dialami oleh pekerja. Contohnya yaitu luka bakar, infeksi saluran pernafasan dan bahkan kematian karena terpapar zat-zat kimia berbahaya dalam laboratorium.

Upaya yang dilakukan oleh pihak perusahaan yaitu dengan cara memberikan sanksi tegas bagi pekerja yang tidak menerapkan standar prosedur K3, melakukan pengawasan dan pembinaan bagi karyawan, memberikan motivasi dan contoh yang benar agar dapat menimbulkan budaya kerja yang aman dan sehat, dan memberikan penghargaan bagi karyawan yang menerapkan standar prosedur K3 dengan baik.

Adapun saran yang bisa diberikan untuk penelitian selanjutnya yaitu peneliti dapat menggunakan teknik analisis dan subjek penelitian yang berbeda terkait dengan kesehatan dan keselamatan kerja (K3) sehingga dari pengembangan tersebut tentunya semakin banyak 
penelitian terkait kesehatan dan keselamatan kerja. Selain itu hasil penelitian ini juga dapat dijadikan bahan pertimbangan bagi perusahaan guna meningkatkan standar K3.

\section{Daftar Pustaka}

Bangun Wilson. 2012. Manajemen Sumber Daya Manusia. Jakarta: Erlangga.

Hanggraeni Dewi. 2012. Manajemen Sumber Daya Manusia. Jakarta: Fakultas Ekonomi Universitas Indonesia.

Ismara, I. 2009. Budaya K3 dan Performansi K3 di SMK. Jurnal Ekologi Pendidikan. Vol. 5 No.1

Kusuma Ibrahim dan Ismi Darmastuti. 2010. "Pelaksanaan Program Keselamatan dan Kesehatan Kerja Karyawan PT. Bitratex Industrie Semarang". Jurnal Manajemen dan Organisasi. Vol. 7 No. 1.

Octaviani, Indri. 2017. "Hubungan Keselamatan dan Kesehatan Kerja (K3) dengan Kinerja Karyawan Pada PT. PLN (PERSERO) Distribusi Jawa Barat Area Bogor". Jurnal Manajemen. Vol. 1, No. 1.

Silaban, Gerry, dkk. 2009. "Kinerja Penerapan Sistem Manajemen Keselamatan dan Kesehatan Kerja Perusahaan Peserta Program Jaminan Kecelakaan Kerja pada PT Jamsostek Cabang Medan". Jurnal Manajemen Pelayanan Kesehatan. Vol. 12, No. 3.

Sofyan, Ade. 2017. "Pengaruh Kesehatan dan Keselamatan Kerja (K3) Terhadap Kinerja Karyawan PT. Bekaert Indonesia Plant Karawang”. Jurnal Manajemen dan Bisnis Kreatif. Vol. 1, No.3.

Somad, Ismed. 2013. Teknik Efektif Dalam Membudayakan Keselamatan dan Kesehatan Kerja. Jakarta: Dian Rakyat.

Soputan, Gabby E.M. 2014. "Manajemen Risiko Kesehatan dan Keselamatan Kerja (K3) Studi Kasus Pada Pembangunan Gedung SMA Eben Haezar". Jurnal Ilmiah Media Engineering. Vol 4, No. 4.

Sugiyono. 2011. Metode Penelitian Kuantitaf, Kualitatif dan R\&D. Bandung: Alpabeta.

Sumar'mur. 2006. Keselamatan Kerja dan Pencegahan Kecelakaan Kerja. Jakarta: PT. Gunung Agung

Suparwo Adi, dkk. 2019. "Pengelolaan Manajemen Keselamatan dan Kesehatan Kerja pada UMKM Bandung Indo Garmen”. Jurnal Pengabdian Kepada Masyarakat. Vol. 2, No. 